\title{
COUNTERING MEASURES OF TERRORISM IN PAKISTAN
}

\author{
Naila Rafique* \& Abdul Manan $\uparrow$
}

\begin{abstract}
Terrorism and sectarian violence has started since the creation of the Pakistan. Terrorism is the deliberate use of unlawful force or violence to achieve goal that is political or ideological nature. Special Anti-terrorist courts enforce the Anti-terrorism laws of the Pakistan and system nominates organizations and people consisted with terrorism. Different factors are responsible to make Anti-Terrorism law. A number of extremist challenges faced by Pakistan that are ethnic and religious groups. The Pakistan government established committees to encourage sectarian harmony and religious tolerance. Pakistan support Taliban in Afghanistan, which make the way safe for militancy and also for terrorists. The anti-terrorism law has massive implication on Pakistan by different ways. Pakistan has been effected economically, politically, socially and militarily. According to Pakistan Finance Ministry, that counter terrorism campaign has caused unemployment in affected areas, which increased poverty. The listing of these proscribes organizations is also one of the factor to make anti-terrorism law. To gauge the impacts of anti-terrorism law, so there is technological impediment inhabits a particular incident of terrorists. Due to this hurdle unintended results happened and they transferred the attack. This law also desisted the activities of those groups who are involved in funds rising, money laundering and participation in terrorist activities. This law has sustainable effect on civil freedom rights and values. Some decision maker was also condemned this act on account of personal liberties. The additional powers of this act have been produced inimical result to combat terrorism.
\end{abstract}

Keywords:Terrorism, Anti-Terrorism Law, Violence, Special Courts, Extremists, Taliban, Proscribe Organization, Civil Freedom

\footnotetext{
Lecturer, Women University Swabi.

$\dagger$ Professor, Shaheed Banazir Buhtto Women University, Peshawar.
} 


\section{Introduction}

Pakistan has adopted Anti-Terrorism laws to subdue activities of extremist or terrorist activities in the country. However, Pakistan doesn't have any specific law about the crimes of extremism, but it does have other connected series of criminal offences i.e. crimes against the state or provocation crimes. The crimes of extremism can be found in Pakistan's penal Code, the Anti-terrorism Act 1997. In Pakistan Extremis is defined in a different ways, i.e. in politics, social contexts and religious. Due to the absence of harmony it is difficult to reach a comprehensive definition of extremism to understand. Special Anti-terrorist courts enforce the Antiterrorism laws of the Pakistan and system nominates organizations and people consisted with terrorism. However, critics have raised questions about effectiveness of the system to deal with terrorism. However, the Pakistan legal perspective to tackling activities of extremism and terrorism became militarized, due to the ignition of military courts to try terrorists. Therefore, countering extremisms is one of the factors to make AntiTerrorism Law.

Pakistan has achieved little success in the regulation and reform of the madrasa education system over the years. An addition to the legal regulations, Pakistan has also strived to start programs encouraging antiradicalization and sectarian balance in the country. There are following factors responsible to make Anti-Terrorism law.

\section{Pakistan Faced Challenges of Extremist Activities}

A number of extremist challenges face by Pakistan that are ethnic and religious groups. According to Muhammad Amir Rana, in Pakistan Extremis is defined in a different ways, i.e. in politics, social contexts and religious. Due to the absence of harmony it is difficult to reach a comprehensive definition of extremism to understand this phenomenon, but it's become more complicated to counter extremism. According to Abdul Basit and Mujtab Rathore, that religious extremism is a common factor which is prevalent in Pakistan all trends and forms of radicalization. Pakistan faces huge challenges from extremists, sectarian violence and terrorism. Some of the present challenges in Pakistan can be detected to the "Islamization" strategy of Pakistan military leader General Zia-UL-Haq. According to International Crisis group report 2009, for the first time radical jihadi groups benefited from state patronage the military regime of General Zia -UL-Haq in the 1980s. They were fighting in Afghanistan at the support of U.S. for the two reasons to support anti Soviet Jihad in Afghanistan and encouraging Sunni group. The state support continues even in the democratic break in 1990s, the military used jihadi group in occupied Kashmir and in 
Afghanistan to support the Taliban. Due to this Sunni groups grew stronger, and sectarian violence becomes the primary reason of terrorism in Pakistan.

Pakistan has been involved in the operations of the military in the northern region of the country against tribal militant since 2001, and action against various organizations in FATA (Federally Administered Tribal Areas) and Baluchistan province separatist movement. In Baluchistan, a low level of insurgency has been waged by separatists and ethno-nationalists for many years. Terrorist and sectarian attacks on the Hazra community of Shia has also resulted sever conflict between military and separatists. The majority of the attacks against the Hazara community have claimed Sunni extremist sectarian groups ${ }^{1}$.

Furthermore, Karachi the most populous city of Pakistan has involved sectarian violence, sectarian militant group and criminal group. The Pakistan law enforcement agencies and military are starting operations against militant in Karachi. So religious extremist and sectarian terrorism become threat for the internal security of country. So for countering violent extremist group i.e. Al-Qaeuda, Therik-e-Taliban (TTP), Lashkar-e-Taiba (LeT), Lashker-e-Jhangvi has banned and make such law to control it activities.

\section{Sectarian Harmony and De Radicalization Programs}

The Pakistan government established committees to encourage sectarian harmony and religious tolerance. In 2010 the Federal Minister for Minorities Shahbaz Bhatti, has formed the National Interfaith Council, which aim to promote harmony, brotherhood within various faiths and sects.

During the conflict of Swat, the Pakistan Army has started number of the de radicalization centers for treatment of militant. The aim of these centers to rehabilitation of the Taliban and gives them vocational skills and cleans their mind from radical teaching. These programs aim to combat extremism and terrorism from the country. According to the committee that special attention shall be given to young and motivate them to bring towards peaceful life.

\section{Madrassas}

Madrassas or seminaries are importing free religious education and make good person. There are views that madrassas have linked to militancy. Particularly madrassas Deobandi is especially rising religious extremism in Pukhtoon are and state of Pakistan. ${ }^{2}$ Pakistan support Taliban in Afghanistan ${ }^{3}$, which make the way safe for militancy and also for terrorists ${ }^{4}$.

\footnotetext{
Human Rights Watch (30 June 2014)."Pakistan: Rampant killing of Shia by Extremists".

Human Rights Watch (2014)."Pakistan: Rampant killing of Shia by Extremists".

A safe heaven for terrorists, (2007), Economist.
} 
Afghan jihad was used a tribal area as a staging ground, so militant has closed connection with each other. Due to this liberty in tribal area, provide religious and military training in the madrassas ${ }^{5}$. During the Afghan Jihad and afterword, the number of madrassas were raised. In Pakistan, approximate 20,000 Islamic seminaries are in operation. The five major madrassas whose heads are belong to Deobandi, Jammat-i-Islami (JI), Salafi, Barelvi and Shia ${ }^{6}$.

Students become aware through the message of hatred only towards other specifically Hindus, Jews and western people ruling in Pakistan. The introduction of Jihad culture is not decreasing madrassa value, but it magnifies Jihad. The education policy has changed and a new education system has started. In President Zia regime five thousands mosque schools are approved and the books were rewritten and also stress on Islamization and jihad. Initial the jihadi-targeting communisms Pakistani Madrassa supplied of funds, arms and religious literature has been given by foreign patrons. Approximate 13 million dollars were given by the United State Agency for International Development (USAID) for textbooks, which were distributed among Afghan refugee camps in Pakistan.

According to the Brooking Institution 2010, that there was closed and strong relationship between civil conflict and education. Different federation that belongs to different Fiqh schools governs these madrassa. Khyber Pakhtoonkhwa (KPK) and Punjab are the main places of madrassa. According to the report of the International Crisis Group (ICG) 2002, that madrassa are used to recruit the militant. In 2002 the Madrassa Registration Ordinance was enforced that register madrassa, and they were also stopped to take foreign sources funding.

\section{Afghan Jihad}

In 1979 extensive changes occurred in the Muslims world and from this y Pakistan could not keep the side from Muslim society. On the outside, the Iranian revolution and the Soviet invasion in Afghanistan were formative events. Due to Iranian revolution the politics of the Meddle East turned to new dimensions. On November 1979, US forces attacked the Holy city Mecca. In 1979, Afghanistan was invaded by Soviet, which was affected by Pakistan foreign policy and also political system. This changed system in Pakistan gave new life to the military dictatorship General Zia and brought Saudi-Iran war in this region. The Wahabi ideology of Saudi and moderate

4 Leon, P. (2012). "U.S. reaching the limits of our patience with Pakistan terror safe haven", Cbs News.

5 Sareen, S. (2005), “The Jihad Factory: Pakistan's Islamic Revolution in the Making”, New Delhi: Har-Anand Publications.

6 Hayat, Kamila (2008), "No more room for doubt and division" The News International Retrieved. 
religious culture system has roots in mystic tradition had dominated position in South Asia.

Geo-strategic location of Pakistan plays an important role in international level. The invasion of Soviet in Afghanistan had affected Pakistan political system. The Soviet invasion brought the Cold War between the two major countries, i.e. Pakistan was in the front line on the side of U.S. Pakistan has condemned the aggression and supported Afghan jihad. Pakistan with U.S cooperated from all sides for the freedom of Afghanistan. The Soviet force was direct threat for Pakistan's territorial integrity and national security because these radical ideologies had developed their roots in the various parts of Pakistan.

The jihadi terrorism ${ }^{7}$ became threat to the national security of Pakistan. The 9/11 attacks and also US captured Afghanistan gave attractive cause to jihad $^{8}$. Pakistan also joined with US to led the war against terror so in this response jihadis turned their guns towards Pakistan. Due to strategic point, Pakistan is the main hurdle between jihad and occupied forces of Afghanistan. The militant started barbaric act of violence, which bring the state in danger. In the world Pakistan was declared unsafe country. Due to common conviction the militants hit easily any target area of Pakistan. The jihadi terrorism also started sectarian terrorism in Pakistan.

\section{Influx of Refugee}

The Afghan civil war resulted two million refugees enter into Pakistan. The majority of these refugees were settled near the border and Khyber Pakhtunkhwa (KPK). In 1986 the refugee's number had grown to four million because the Afghanistan political situation was not stable. There were also movement of weapons with refugees over Pak-Afghan boarder but the government had control over weapon up to some extent. The tribal belt of Pakistan FATA has been control of the Frontier Crimes Regulation (FCR) and political agent (PA). The militant growth rises easily in FATA because protection was granted by Zia campaign of Islamization. Those refugees who had found work in Afghanistan they had returned, but according to the count of 2006, still in Pakistan 2.5 million Afghan refugees are present. These refugees are responsible for the enlisting militant, giving safe place for criminals and terrorists and also smuggling of weapon into Pakistan. They were also responsible sectarian clashes in Kurram agency. These militants are big challenges for Pakistan to eradicate from the country. The hilly areas are a favorite place for the militant organizations. These militant wants to implement his own view in Pakistan and then in another country.

7 Ahmed, R, (2002), "Jihad The rise of militant Islam in Central Asia, New Haven", Yale University Press, p. 2.

8 Maurits, B, (2006), "Sharia. Islam tussen recht en politiek. The Hague", Boom Juridische Uitgevers, p. 203. 


\section{The National Laws of System Aimed to Fight Against Terrorists, Extremist Activities}

From the past, Pakistan has adopted an Anti-terrorism law against extremist, terrorists and sectarian violence in the country. Due to increasing political and sectarian violence in the country Pakistan, then Anti-terrorism Act 1997 was promulgated by the government of Nawaz Sharif. Pakistan has passed a number of Anti-terrorism laws, amendments, national Counter terrorism Authority Act, and the investigation for Fair Trial Act, the Pakistan Protection Act from last few years. In 2013,the Nawaz Sharif government adopted the same policy as the earlier time to counter terrorism through five elements, contain, prevent, dismantle, reintegrate militants and educate. The Prime Minister announced 21 points of the National Action Plan to counter terrorism and established military courts to try terrorists, reinforce NATCA and extremist material in December 2014 after the massacre of student in army school Peshawar. After $21^{\text {st }}$ Constitutional Amendment Act, the Antiterrorism law efforts become more militarized and give structure to set up military courts to try terrorists. To fight against extremist terrorist is one of the factors to make Anti-Terrorism Law because government wants to dismantle the network of extremists.

\section{Sectarian Harmony and De Radicalization Programs}

The Pakistan government established committees to encourage sectarian harmony and religious tolerance. In 2010 the Federal Minister for Minorities Shahbaz Bhatti, has formed the National Interfaith Council, which aims to promote harmony, brotherhood with various faiths and sects.

During the conflict of Swat, the Pakistan Army has started number of the de radicalization centers for treatment of militant. The aims of these centre is to rehabilitation of the Taliban and give them vocational skills and clean their mind from radical teaching. These programs aim is to combat extremism and terrorism from the country. According to the committee that special attention shall be given to young and motivate them to bring towards peaceful life.

\section{Impacts of Anti-Terrorism Laws}

The anti-terrorism law has had massive implication on Pakistan by different ways. Pakistan has been effected economically, politically, socially and militarily. The constant war on terror has caused social disturbance in Pakistan. Million of people have been displaced by the operation in Swat. The numbers of refugees were more than Afghan refugees, which were affected by the Soviet invasion. Likewise, from FATA half million of people were displaced by war on terror. Due to the refugees, the administration has 
faced many problems. On other side US drone attacks are raising hatred among youth and to take revenge from US. As a result, it provides an opportunity to TTP to give preaching against US because it is on the front line. Due to drone attacks killed 2283 Pakistani up to 2010.

According to Pakistan Finance Ministry, that counter terrorism campaign has caused unemployment in affected areas, which increased poverty. Prolong military operation has also weakened federation. The Pakistan Army has great success war on terror.

\section{Related Crimes and Crime of Extremism Terrorism}

In Pakistan, there is no particular law about the crime of extremism, but it does have laws of terrorism offences and other crimes, which are nearer to the activities of extremism. Under international conventions and statutes of other countries have defined crime of extremism. Literally meaning of extremism is the quality being extreme. Extremism is the activities (feeling, strategies, beliefs, actions, attitude) that are removed from the character and ready for conflict etc. The extremist is person who uses violence against the society. Similarly there are certain other crimes, which are related to extremism and terrorism, but it is not explain another law. Any type of publication that creates religious, ethnic hatred is a criminal offence. Hence, all these things responsible to make Anti-terrorism Law, which deal crime of extremism, terrorism and all relevant crimes.

As is discussed above, in Pakistan Anti-terrorism laws adopted in the country to suppress sectarian violence and extremist activity. According to the section 6 of the Anti-terrorism Act, terrorism mean "the use of threat, coerce or intimidate or produce insecurity in society or fear over the public or community or Government or foreign government or international organization". OR Threat is using for the promotion of religion, sectarian, racial reason OR frighten media persons, social sectors, profession, group or attacked the civil people and also damaging the property or fire any means, law enforcement agencies or government officials". According to the Antiterrorism Act 1997, separate crime defines as, "that prohibit the act deliberated to stair up sectarian aversion".

According to the section 8 of the Anti-Terrorism Act, " a person who uses frightening, derogatory, or using insulting words or behavior or distribute in writing material or displays or show or plays recording or visual or sound or has possession of any written material or recording, visual or sound which is frightening or threatening or insulting or other". A person shall be guilty of that offence because he stirs up hatred with intention or having all conditions that stirred up sectarian hatred and violence. And also any type of publication, printing, or statements that creates sectarian, religious or ethnic hatred is a criminal offence. However, to include certain offence within scope of Antiterrorism Act 1997, so the offence should be connected to the object of this act i.e. terror, panic, or creating insecurity among the people. Similarly, civil commotion is also prohibited under the 1997 Act. 
Any offence against the state, to wage war or to do conspiracy is prohibited under Pakistan Penal Code. Furthermore, any means of criminal force or to show such force, the Federal Government or Provincial Government or conspiracies deprive sovereignty of the any territory of Pakistan is criminalized. According to the section 153-A of Pakistan Penal Code, the encouragement of any hostility or conflict between different groups is criminalized. No subject is allowed to write or do anything or say which provoke other class of subject. Hence these are related crimes of terrorism and extremism that responsible to make Anti-Terrorism Law.

\section{Listing of Proscribe or Prohibit Organizations}

There are certain organizations that are involved in terrorism activities. These organizations are helping terrorists in shape of money, publication material, literature and distribution of publication etc. So the listing of these proscribes organizations is also one of the factor to make anti-terrorism law.

The Federal Government has empowered to list or proscribe or prohibit any organization if it is involved or concerned with terrorism, prepare for terrorism, participation to commit terrorism, supports any organization concerned in terrorism, to raise hatred feeling and stir up religious or sectarian violence, expel those who commit acts of terrorism or any way concerned with terrorist. The list of such organizations is present under First Schedule of Antterrorism Act. According to this law action will be taken against such listed organization to seal their offices, to confiscate poster, banners, literature or other materials. The Federal Government imposes ban on its publication, distribution, printing, any conference or who support such listed organization.

\section{Trails and Prosecution of Suspected Terrorists}

There are many heinous offences of terrorism and numbers of them are acquitted in criminal courts because criminal courts haven't command to deal terrorist cases. According to record, in Punjab $75 \%$ of suspected terrorists were arrested by the Provincial Government and set free over the last two decades. The investigation process of law is also defective due to law enforcement agencies. Critics argue that police officers have lack of skill in collecting evidence and also lack of modern forensic tool, which has led to ineffective investigation process in Pakistan. Furthermore, Pakistan has an absence of witness protection, so witnesses and complainants refuse to give evidence against the accused or become his enemy. Some of the people have given their views that absence of a mechanism to handle the record of release suspected terrorists or acquitted or on bail.

All these factors are responsible to make Anti-Terrorism Law in Pakistan, which deal terrorism cases. There is also special courts i.e. Anti-Terrorist Courts (ATCs) are established. This law also gives protection to the witnesses 
and complainants to give evidence. The purpose of these courts is to give speedy trials of heinous crimes. These ATCs has jurisdiction, only that crimes, which are, specify under the Anti-terrorism Act. Additionally, these ATCs also try those crimes, which has not clear connection with terrorism but such offences are included in the Third Schedule of Anti-terrorism Act. These court decisions are appealable in High Court and Supreme Court. Federal and Provincial Government establish these courts. Under this anti-terrorism law the investigation process is effective to deal handling the cases. In some cases ATCs trails are delayed due to security reason so that reason, in jail in-camera trials are conducted. Under this Anti-Terrorism Law the record of release suspected terrorists or acquitted or on bail is check by scientific methods. In response from them, in 2011 the Actions (in Aid of civil Power) Regulation 2011, was established, that provide legal system and the transfer of arrested person to civilian custody under criminal law of Pakistan. Under the Pakistan Protection Act 2014, the government of Pakistan has established special military courts and tries the terrorists, due to the response of Peshawar school attack in 2014. In January 2015, the $21^{\text {st }}$ Amendment Act and the Pakistan Army (Amendment) Act, 2015 was passed to organize military courts and to try civilian terrorists. These courts established to handle terrorists related cases and ineffectiveness of Pakistan's criminal justice system. According to Pakistan Army (Amendment) Act, they are providing protection to the security of Pakistan against the threats of terrorist group, militia, armed group or their members are using name of religion.

\section{Responses of the Government on Legislative Initiative and Preventive Measures}

\section{National Counter Terrorism Authority}

Pakistan has faced continued challenges and this response to interagency cooperation and coordination to counter terrorism. However, in the last few years Pakistan has made effort to coordinate and share information with authority of counter terrorism. The Pakistan government has established National Counter Terrorism Authority (NCTA) in December 2009. This authority started operating under the Interior Minister. This authority was criticized because it was effectively low and lacking of independence to government department rather than it position in the country's premier in the counter terrorism organization. The Nation Parliament of Pakistan passed the Act of Counter terrorism Authority (NACTA Act) and gave a status of independence in 2013.

The main aim of this act is to counter extremisms and terrorism. Under this act the task of presenting government strategic policy and executed by stakeholders and also responsible for managing scientific studies on terrorism and extremism. NACTA is composed of a Board of Governors, the Prime Minister, a number of Federal and Provincial Ministers, law 
enforcement and intelligence agencies, Military Intelligence and other. This act establishes the position as a coordinator and help in executing board passed polices and plans. Some criticism has pointed that the body of NACTA is still inoperative and it is so far to its aims and scope. However, in February 2014, the government has revived national security policy. In December 2014, after the attack on Peshawar school the Federal government announced that NACTA is the part of National Action Plan (NAP).

\section{Madrassas and Education Reform}

Another factor responsible to making Anti-Terrorism Law is reform of madrassas because it is controversial issue in Pakistan ${ }^{9}$. It is consider growing of terrorism and extremism in Pakistan ${ }^{10}$. So it needs make such law that control spreading and growing of terrorism and extremism.

In 2001 President Musharraf period, Madrassa Education Board Ordinance was promoted. The responsibility of this Board to establish new Dinimadaris i.e. religious schools and colleges, and Darul Uloom i.e. Islamic seminaries and supervise these madrassas and also registered with the Board. On June 2002, second ordinance was passed, that is Dini Madaris (Regulation and Control) Ordinance, in these madrassas allowed on a voluntary basis and give details of financial reports to the government.

In 2007 the government and madrassas passed another amendment to the Societies Registration. According to this amendment, madrassas must sign an agreement that they shall not promote militancy or publish any literature. These madrassas also required submitting regular financial reports. The government also compromise with two demands of madrassa, "(1) already registered madrassas didn't have obey new requirements and (2) madrassas financial reports didn't disclose.

According to National Action Plan (NAP) 2014, the government called reform of madrassa system and specifically enforce registration of foreign funding. However, the ITMD has seriously resisted the government steps on the previous agreement on madrassas reform. At last the ITMD and the government agree to the registration of madrassas agreement and submit their audit reports and create foreign funding, monitoring with the help of the State Bank of Pakistan.

\section{Hindrance to Evaluate the Impact of the Anti-Terrorism Law}

To gauge the impacts of anti-terrorism law, so there is technological impediment inhabits a particular incident of terrorists. Due to this hurdle unintended results happened and they transfer the attack. So metal detectors were installed, but it increased terrorist activities and death tolls. In this law,

\footnotetext{
9 Fazal, R. (2007), "Discourse on Madrassa Education Reform in Pakistan", published Al bashar, Discourse on Madrassa Education Reform, vol: 8, issue, 1.

${ }^{10}$ Zahid, H. ( 2004), “ front line terrorist violence in Pakistan”, South Asian portal Index.
} 
there is not a substantial investigation process and also there isn't preventive arrest power. This act addresses about the investigation process and legal reforms, but not about the funding of law enforcement agencies and security. There is no guarantee about the effective operations of additional resources. It is difficult to measure deterrence that terrorist events happened to a particular intervention or just the absence of threats.

\section{Effects of the Deterrent Increased Intelligence in Prosecutions}

This law has had a strong hindrance effect on those who are supporting banned organizations. This law also desisted the activities of those groups who are involved in funds rising, money laundering and participation in terrorist activities. The prohibitions of these activates motivate common elements within the Muslim community to stop terrorist activities. The intelligent function has been also increased by this act. The activities of terrorist, communication and funding are intercepted by intelligence in the country. The lack of prosecution, preventive detentions and evidence do not exclude the effectiveness of criminal law.

On other side threat is being used for non-cooperation of prosecution or court contempt held, so is not effective result to determine a terrorist in case. The adopted measures were too tough to handle religious and political extremists or those who are involved with terrorist groups. But these measures are inadequate for those who are committed to die for this.

\section{Symbolic Benefits of the Act}

This act produced some advantages inside and outside the country against terrorism activities. The approval of this act government took serious action against terrorism. Through this action, government protected the people and maintains commerce in the country.

\section{The Issue is Related to the Definition of Terrorism and Scope of the Act}

Many participants have given their concern about the definition of terrorism, but the absence of consensus the definition of terrorism was relative concept. Some scholars criticized the definition of terrorism to include motive "religious, political, ideological cause". To prove the terrorist act is committed for political and religious motives so the police officer investigates the religious and political suspected terrorists. According to this aspect this act is limits the scope of crimes of terrorism and it is difficult to make conviction.

The broad definition of terrorism in this act of purpose of immigration law that any action which cause death or injury to civilian or purpose to 
intention to threats, general public or compel an international organization to do or not to do a certain act. But this definition criticized by many people because the expansion of the definition of terrorism under this act caused danger the due process of immigration law.

The criminalization of the commission of terrorist activities and broad range proceeding are included in this act (i.e. assistance and finance of a terrorist group) but there is a lack of relation to plan terrorist act.

\section{The Impact of this Law on Civil Liberties and Values}

This law has the sustainable effect on civil freedom rights and values. Some decision maker was also condemned this act on account of personal liberties. This act increased investigation and detention power by the interchange of civil liberties. However, this act showed failure in the war against terrorism. There are many questions aroused on investigation power, that police is empowered to ask questions from a person about terrorist activities past or future. This investigation power constitutes unwanted invasion of traditional criminal justice to tackle serious crimes. However, ambivalent opinion about the expended investigation power has been used to prevent terrorist acts.

Due to the additional powers of this act has been produced inimical result to combat terrorism. The right way of using of this process, not only ensures the transparency, but also decreases the chance of inaccuracy. If a meaningful action will take against terrorist investigation so there will reduce error.

This act is the sustainable effect on civil freedom rights and values. Some decision maker was also condemned this act on account of personal liberties. This act increased investigation and detention power by the interchange of civil liberties. However, this act showed failure in the war against terrorism. There are many questions aroused on investigation power, that police is empowered to ask questions of a person about terrorist activities past or future. This investigation power constitutes unwanted invasion of traditional criminal justice to tackle serious crimes. However ambivalent opinion about the expended investigation power has been used to prevent terrorist acts.

Due to the additional powers of this act has been produced inimical result to combat terrorism. The right way to use of this process, not only ensures the transparency, but also decreases the chance of inaccuracy. If a meaningful action will take against terrorist investigation so there will reduce error. 


\section{The Impact of the Anti-Terrorism Law on Specific Groups and Organization}

This law has disproportionate impact on specific groups and organization. Under this some agreement was made with different organizations, " that they are as a sure diligence to refrain any wrongful allegations of terrorist, even doubt of such activity could damage their necessary public support."

The list of terrorist groups and individual because they were supporter and exercise anti lobbying against different groups, e.g. Lashkarjangvi, Jash Muhammadi etc ${ }^{11}$. In the result of listing organizations caused worsened relation between inter-ethnic and religious group. By the listing of these organizations and groups caused discrimination, perception among the people toward the affected people.

It is necessary for the proper investigation a yardstick to be used for targeting investigation. It needs vigilance measure to be listing any terrorist groups. As the consequence of stigmatization of listing terrorist groups should need standard of proof afar confusion in a criminal trial.

\section{Issues of Accountability and Oversight}

Approximate half of the participant expresses their view about inaccuracy mechanisms of this act. Because they feel that law enforcement agencies and some executive powers hasn't sufficient reviewed listing the terrorist groups. The paramount defect of this act may be " the miscarriage of government to make a suitable comprehensive accountability and review, that cover all sides of national security function." In this act also lack of significant check on police activities i.e. an investigation process that how long it will be lengthy or obtrusive. It is not protecting from deterrent arrest, formal charges or an investigation, is protected from any significant review.

This Act accredits the executive branch, i.e. cabinet to appoint individuals and groups as terrorist. There is also a judicial review of this act, but such reviews unexpected disallow the appointment of terrorists. These reviews will be organized in camera, but the absence of applicants.

\section{Conclusion}

Due to the absence of harmony it is difficult to reach a comprehensive definition of extremism to understand. Special Anti-terrorist courts enforce the Anti-terrorism laws of Pakistan and system nominates organizations and people consisted with terrorism. An addition to the legal regulations, Pakistan has also strived to start programs encouraging anti-radicalization

${ }^{11}$ Laurie, F. (2010), "Protecting home land from international and domestic terrorism threats". 
and sectarian balance in the country. Pakistan has been involved in the operations of the military in the northern region of the country against tribal militant since 2001. So for countering violent extremist group i.e. Al-Qaeuda, Therik-e-Taliban (TTP), Lashkar-e-Taiba (LeT), Lashker-e-Jhangvi has banned and make such law to control it activities.

According to the report of the International Crisis Group (ICG) 2002, that madrassa are used to recruit the militant. In 2002 the Madrassa Registration Ordinance was enforced that register madrassa, and they were also stopped to take foreign sources funding. The aims of these center to rehabilitation of the Taliban and give them vocational skills and clean their mind from radical teaching. These programs aim to combat extremism and terrorism from the country. According to the committee that special attention shall be given to young and motivate them to bring towards peaceful life.

The Nation Parliament of Pakistan passed the Act of Counterterrorism Authority (NACTA Act) and gave a status of independence in 2013. The main aim of this act is to counter extremisms and terrorism. Under this act the task of presenting government strategic policy and executed by stakeholders and also responsible for managing scientific studies on terrorism and extremism.

\section{Bibliography}

Muhammad, A.R. (2010). “Abstract, Litterateurs' Response to Extremism in Pakistan”, 3 PIPS Res. J. Conflict \& Peace Study.

Abdul, B. \& Mujtaba, M. (2010). "Trends and Patterns of Radicalization in Pakistan, 3 PIPS Res. J. Conflict \& Peace Study".

1Asia Report No. 164, (2009). "International Crisis Group, Pakistan": The Militant Jihadi Challenge.

Reuters Africa. (2011). Bomb Blast at Hotel Kills 11 in Southwest Pakistan.

Saira, Y. \& Salma, M. (2014). "United States Institute of Peace, Mapping Conflict Trends in Pakistan.

Omar, H. (2015). “Military Intervention Has Reduced Terrorism Risks in Karachi”, IHS Jane's 360.

Shehzad, H.Q. (2011). "De-radicalizing the Pakistani Taliban", HuffPost Religion.

Baqir, S. (2011). 'De-Radicalisation' Plan Under Study, Dawn.

Mohammad, W. (2007). "Origin and Growth Patterns of Islamic Organization in Pakistan, Asia-Pacific Centre for Security Studies, pp: 28.

Nasim, A. (2010). "The Islamization of Pakistan"es Educational System: 1979-1989," cited in "The Islamization of Pakistan , The Middle East Iinstitute, Washington DC. 
Hussain, T. (2010). "Post-1979 Pakistan: What Went Wrong?" cited in "The Islamization of Pakistan 1979-2009: A Special Edition of Viewpoints," The Middle East Institute, Washington DC.

Mehrunnisa, A. (2001). "Readings in Pakistan Foreign Policy 1971-1998", New York: Oxford University Press, p 332.

Daniel A.K. (2007). "Afghan Refugees in Pakistan: Not All Refugees, Not Always in Pakistan, Not Necessarily Afghan?" Journal of Refugees Studies.

Mehrunnisa, A. (2001). "Readings in Pakistan Foreign Policy 1971-1998", $\mathrm{p}, 335$.

Baqir, S. (2013). No Radical Shift in New Anti-terror Strategy, Dawn.

Abdul, M. (2013). "Fight Against Terrorism: Defining Moment", The Express Tribune.

A, Ishfaq. (2008). "Anti-Terrorism Act, 1997": With All Amendments \& Up-to-date Case Laws Al-Noor Law Book House.

Shaukat, M. \& Shaukat, N. 2008. "The Pakistan Penal Code: Exhaustive Commentary Incorporating Case-law of Pakistan”, Bangladesh, Burma, India, U.K., Legal Research Centre.

Flawed, A. (2011). “Anti-terrorism Strateg"y: 75\% Terror Suspects Set Free in Punjab, The Express Tribune.

Huma, Y. (2010). "Pakistan's Anti-Terrorism Courts", CTC Sentinel.

Christopher. C. (2005). "Pakistan's Recent Experience in Reforming Islamic Education”, in Robert M. Hathaway, Education Reform in Pakistan.

Borchgrevink, K. (2011). "Taking Stock: Madrasa Reform in Pakistan", NOREF Policy Brief No. 4 at 5 July.

M, Imran. (2015). "Deadlock Persists on Madrassa Reforms", Stop Harassing Clerics, Identify Those Involved in Terrorist Activities,

Abrar, I. (2015). "With Army Chief on Table, PM Brings Clergy on Board", Madrassas As Through Banks, The Nation. 